Erratum

\title{
Simultaneous insulation and modification of quartz tuning fork surface by single-step plasma polymerization technique with amine-rich precursors - ERRATUM
}

Gizem Kaleli Can, Pelin Kömürcü, Hatice Ferda Özgüzar, Gözde Kabay, and Mehmet Mutlu

doi: https://doi.org/10.1557/mrc.2018.79, Published by Materials Research Society with Cambridge University Press, 26 April 2018

In Kaleli Can et al., ${ }^{1}$ the authors were presented in the wrong order. The correct order of the authors is as follows:

Gizem Kaleli Can, Pelin Kömürcü, Hatice Ferda Özgüzar, Gözde Kabay, and Mehmet Mutlu

The publisher apologies for this error and the original has been updated.

\section{Reference}

1.G. Kaleli Can, P. Kömürcü, H. Özgüzar, G. Kabay, and M. Mutlu: Simultaneous insulation and modification of quartz tuning fork surface by single-step plasma polymerization technique with amine-rich precursors. MRS Comm. 8(2), 541-549, doi: 10.1557/mrc.2018.79 (2018). 